\title{
Potential and clinical relevant drug-drug interactions among elderly from nursing homes: a multicentre study in Murcia, Spain
}

\author{
Interações medicamentosas potenciais e clinicamente relevantes \\ em instituições de longa permanência para idosos: um estudo \\ multicêntrico em Murcia, Espanha
}

Carles Iniesta-Navalón (https://orcid.org/0000-0002-3950-7250) ${ }^{1}$

Juan Jose Gascón-Cánovas (https://orcid.org/0000-0002-2128-225X) ${ }^{2}$

Zenewton André da Silva Gama (https://orcid.org/0000-0003-0818-9680) ${ }^{3}$

José Francisco Sánchez-Ruiz (https://orcid.org/0000-0003-2402-1415) 4

Erick Angelico Gutiérrez-Estrada (https://orcid.org/0000-0002-8048-4732) ${ }^{4}$

Ernesto De-la-Cruz-Sánchez (https://orcid.org/0000-0002-4718-7058) ${ }^{2}$

Owen Harrington-Fernández (https://orcid.org/0000-0003-4915-2059) ${ }^{5}$
${ }^{1}$ Farmacia Hospitalaria, Hospital General

Universitario Reina Sofia.

Av. Intendente Jorge

Palacios 1. 30003 Murcia

Espanha.carles424@

hotmail.com

${ }^{2}$ Universidad de Murcia.

Murcia Espanha.

${ }^{3}$ Departamento de Saúde

Coletiva, Centro de Ciências

da Saúde, Universidade Federal do Rio Grande do

Norte. Natal RN Brasil.

${ }^{4}$ Subdirección General

de Informática. Servicio

Murciano de Salud. Murcia

Espanha.

${ }^{5}$ National University of

Ireland. Galway Irlanda.
Abstract This study purposes to determine the prevalence of potential and clinical relevant Drug-Drug-Interactions ( $p D D I s)$ in institutionalized older adults and to identify the pertinent factors associated. We conduct an observational, multicenter and cross-sectional study during the last quarter of 2010. We selected a sample of 275 subjects (aged $\geq 65$ years) from 10 nursing homes of Murcia (Spain) by a two-stage complex sampling. pDDIs were identified using the College of Pharmacists Database. We only considered pDDIs of clinical relevance, and thereafter the relevant factors were identified through uni-level and multi-level regression analyses. A total of 210 pDDIs were identified, 120 of which were considered clinically relevant (57.1\%), affecting a total of 70 elderly (25.8\%). Eight pharmacological groups made up 70.2\% of the clinically relevant $p D D I s$. More clinically relevant DDIs were found in people suffering several pathologies $(\mathrm{OR}=2.3 ; 95 \% \mathrm{CI}=1.4-4.5)$, and also in people who take ten or more drugs daily $(O R=9.6 ; 95 \% C I=4.8-19.1)$, and people who take anti-inflammatory drugs $(\mathrm{OR}=3.9 ; 95 \% \mathrm{CI}$ $=1.4-10.4)$. This study reveals that clinically relevant $p D D I$ are very common in institutionalized elderly people, and that caregivers should aim at improving their practice in order to reduce the prevalence of this phenomenon.

Key words Potential drug interactions, Elderly, Homes for the aged
Resumo Este estudo pretende identificar a prevalência de interações medicamentosas potenciais (IMP) em idosos institucionalizados e seus fatores associados. Realizamos um estudo observacional, multicêntrico e transversal, durante o último trimestre de 2010. Selecionamos uma amostra de 275 sujeitos ( $\geq 65$ anos) de 10 instituições para idosos de Murcia (Espanha) mediante amostragem aleatória complexa em duas etapas. As IMP foram identificadas usando a base de dados do College of Pharmacists. Estimamos a prevalência de IMP de relevância clínica e analisamos os fatores associados com análise de regressão uni e multinivel. Identificamos 210 IMP, das quais 120 foram consideradas clinicamente relevantes $(57,1 \%)$ e afetaram 70 idosos (25,8\%). Oito grupos farmacológicos constituíram $70,2 \%$ das IMP clinicamente relevantes. A prevalência de IMP esteve associada à multimorbidade $(\mathrm{OR}=2,3$; IC $95 \%=1,4-4,5)$ e tomar dez ou mais medicamentos diariamente $(O R=9,6$; IC95\% $=4,8-19,1) e$ uso de medicamentos anti-inflamatórios $(\mathrm{OR}=$ 3,9; IC 95\% = 1,4-10,4). Este estudo revela que as IMP clinicamente relevantes são muito comuns em idosos institucionalizados e que os serviços devem melhorar seus processos para reduzir a prevalência deste fenômeno.

Palavras-chave Interações medicamentosas potenciais, Idosos, Instituições de longa permanecia para idosos 


\section{Introduction}

The high number of iatrogenic diseases is a prevalent health problem, especially in the elderly, and as such, there are several national and international public health institutions - for whom patient welfare is paramount - that are interested in studies that aim to find solutions to this problem $^{1}$. Drug-drug interactions (DDIs) are one of the main health problems associated with drug use: around five percent of drug use-related side effects in primary care could be caused by DDIs ${ }^{2}$. Also, a total of $6.7 \%$ of hospitalization cases is due to the side effects caused by drugs ${ }^{3}$, and around $60 \%$ of these cases could be prevented ${ }^{3,4}$.

Elderly patients are at a higher risk of suffering from DDIs due to their susceptibility to chronic diseases and to the complexities of their treatments 5 . For adults older than 65, around $4.8 \%$ of hospitalizations are related to $\mathrm{DDIs}^{6}$. Polypharmacy and multimorbidity are the leading conditions related to DDIs incidences and both are very common in most elderly people ${ }^{7}$. Older adults that reside in nursing homes tend to use a variety of medicines in greater numbers and in larger doses, a situation that stems from their predisposition for chronic diseases and their poor health status in comparison to adults that live in the community ${ }^{8,9}$. Moreover, it has been noted that other patient-related variables such as frailty, low physical fitness, poor mental health and inter-individual variability, (variables that are very common in the institutionalized elderly), could increase the difficulty of drug management and the prevention of pDDIs in older adults ${ }^{10}$.

Because of its importance to public health, this is a topic that has gained prominence in recent years $^{11,12}$, despite this, however, there is a lack of studies that focus on the prevalence of DDIs among institutionalized elderly people. This is precisely the aim of our study: to determine the prevalence of clinically relevant pDDIs in institutionalized older adults, and to identify the associated factors.

\section{Methods}

This is an observational, multicenter, cross-sectional study. The study assess people over 65 years living in the nursing homes network of Murcia (a region in the southeast of Spain with 3,635 residents in 46 nursing homes).

Nursing home residents were selected using a two-stage complex sampling method. In the first stage, 10 out of 46 nursing homes were randomly selected. A random selection of elderly people was drawn from the sampling frame of the selected nursing homes in the second stage. The resulting sampling fraction was the same for the 10 nursing homes. Patients who were hospitalized or who suffered from severe psychiatric diseases were excluded from this study.

The indented sample size was 319 subjects. This number resulted from the formula for estimating a proportion in infinite populations (precision 5\%, confidence $95 \%$, prevalence $35 \%$ ) and adjustment by the finite population of 3,635 residents.

Data were obtained from the clinical record of each nursing home. The information collected was recorded in a computerized database designed for this purpose, using the Microsoft Access $^{\circledR}$ application. This database was anonymized prior to any analysis to ensure data protection. The variables accounted for in this study are related (a) the patient: age, sex, chronic disease, presence of multimorbidity; and (b) pharmacotherapy (use chronic, for at least 3 moths): drug use, number of drugs, drug type. Chronological clinical reports were studied in order to gather pharmacological history, sociodemographic data of each participant (age, sex, nursing home) and the diseases from which they suffered. People using ten or more drugs chronically (for at least three months) were considered "polypharmacy patients". Those with more than three chronic diseases were considered "multimorbidity patients". The generic denomination of each drug and the date it was first administered were registered, and all the drugs were classified the according to Anatomical Therapeutic Chemical Classification System (ATC) of the World Health Organization (WHO).

The identification of pDDIs was established using the Spanish College of Pharmacists' online software resource, $\mathrm{BOT}^{13}$, as this database met the minimum quality criteria established by Rodríguez-Terol et al. ${ }^{14}$. In this database, pDDIs were classified into four groups according to their severity: relevant, potentially relevant, relevant only in special circumstances and irrelevant. Only relevant pDDIs were considered for this study; following this, aided by the information registered in the aforementioned database (BOT), relevant pDDIs were classified according to their clinical profile: widely clinically studied, described only in rare cases or theoretically. Additionally, the pharmacological mechanism of action (pharmacokinetics and pharmacodynamics), effect of 
each drug interaction, and recommendation for management was obtained.

A descriptive analysis was established for the aforementioned variables: quantitative data were expressed in terms of mean and standard deviations, and qualitative data were expressed in terms of frequency and percentages. Chi-square test, followed by post hoc standardized residual analysis, and T-student were applied in the analysis of qualitative and quantitative variables respectively for comparison between patients with and without pDDIs. Bivariate correlations were employed to establish the relationship between quantitative data. Multivariate logistic regression (step forward procedure) was employed, to adjust for possible confounding effects among the variables, in order to identify associated factors. Those factors previously defined as statistically significant according to the univariate regression analysis were entered in the model; OR were estimated with their corresponding 95\% confidence interval. A power sample was done "post hoc" for the logistic regression model to determine 1-beta error for large effect sizes (OR 32.0 ) and alfa error of 0.05 . All procedures were developed using SPSS $15.0^{\circledR}$ and GPower $3.1^{\circledR}$. A value of $\mathrm{p} \leq 0.05$ was interpreted as significant.

\section{Results}

Despite the initial intention to evaluate 319 subjects, we were able to include 315 subjects in the initial sample. In addition, we had a loss of $12.5 \%$, because one institution gave up participating in the study $(\mathrm{n}=40)$. Our final sample consisted of 275 subjects (Figure 1 ).

The ages of the nursing home residents ranged from 65 to 100 years (average $81.6 \pm 7.7$ years), women represented the majority $(61.5 \%)$. The $34.2 \%(n=94)$ of studied patients exhibited multimorbidity; the most common chronic diseases in the sample are as follows: hypertension $(56.6 \%)$, rheumatic diseases $(36.0 \%)$, diabetes (22.9\%) and cardiovascular diseases, (20.4\%), which includes atrial fibrillation and heart failure among others. Hypertension and AF/heart failure were $1.4(\mathrm{p}<0.05)$ and $2.3(\mathrm{p}<0.01)$ times more frequent respectively in patients with pDDIs than in those without it. Besides, only one above ten persons without pDDIs used 10 or more drugs simultaneously while this figure is
4 times higher among patients with pDDIs $(\mathrm{p}<$ 0.05), (Table 1).

A total of 1810 medicines were observed, $6.6 \pm 3.8$ drugs per person. $20.7 \%$ of the studied sample used ten or more drugs chronically, and the five types of most used drugs were, in descending order: psycholeptics (12.9\%), psychoanaleptics $(8.7 \%)$, proton pump inhibitors (PPI) $(8.1 \%)$, renin-angiotensin, antihypertensives (7.2\%) and antithrombotics (5.4\%). 210 pDDIs were detected, of which 119 were clinically relevant, affecting a total of 70 patients $(25.8 \%$ $\pm 6.8 \%$ ). Relevant pDDIs distribution was as follows: one potential interaction in 39 patients $(14.2 \%)$, two potential interactions in 20 patients (7.3\%), and more than two potential interactions in 11 patients $(4.0 \%)$. According to the mechanism of action, $42.0 \%$ were pharmacokinetics and $55.5 \%$ pharmacodynamics, and according to their evidence level, $69.1 \%$ were widely clinically studied and $30.9 \%$ were described only in rare cases.

Eight pharmacological groups (diuretics, bronchodilators, antithrombotics, myocardial-related drugs, calcium salts, renin-angiotensin inhibitors antihypertensives, PPI and psycholeptics) were related to $70.2 \%$ of the DDIs. Table 2 shows the pDDIs in pairs and their respective effects, the proposed measurement by the BOT database and its severity. The most frequent drug pair combination was acenocumarol-omeprazol, followed by alendronic-calcium and digoxin-furosemide. The most frequently found drugs in the observed pDDIs were, in descending order: furosemide $(12.2 \%)$, acenocumarol $(9.7 \%)$, calcium $(7.1 \%)$, digoxin $(6.7 \%)$ and omeprazol $(5.5 \%)$. Most of the side effects of pDDIs were related to the circulation system (atherothrombotic events, hemorrhage and cardiac arrhythmias). As Table 2 graphically demonstrates, $9.2 \%$ of the recommendations given by the BOT database were devised to avoid association, and in $80.7 \%$ of the total patient monitoring was advised.

The number of pDDIs seems to be moderately correlated with the amount of drugs used (Pearson's $r=0.536, p<0.001)$. As seen in Table 3 , independently associated variables with prevalent pDDIs were multimorbitidy (OR: 2.3, CI 95\%: 1.4-4.5), use of 10 or more drugs (OR: 9.6, CI 95\% 4.8-19.1), and the use of antiinflammatory drugs (OR: 3.9, CI 95\%: 1.4-10.4). "Post hoc" statistical power of test was high (94.1\%). 


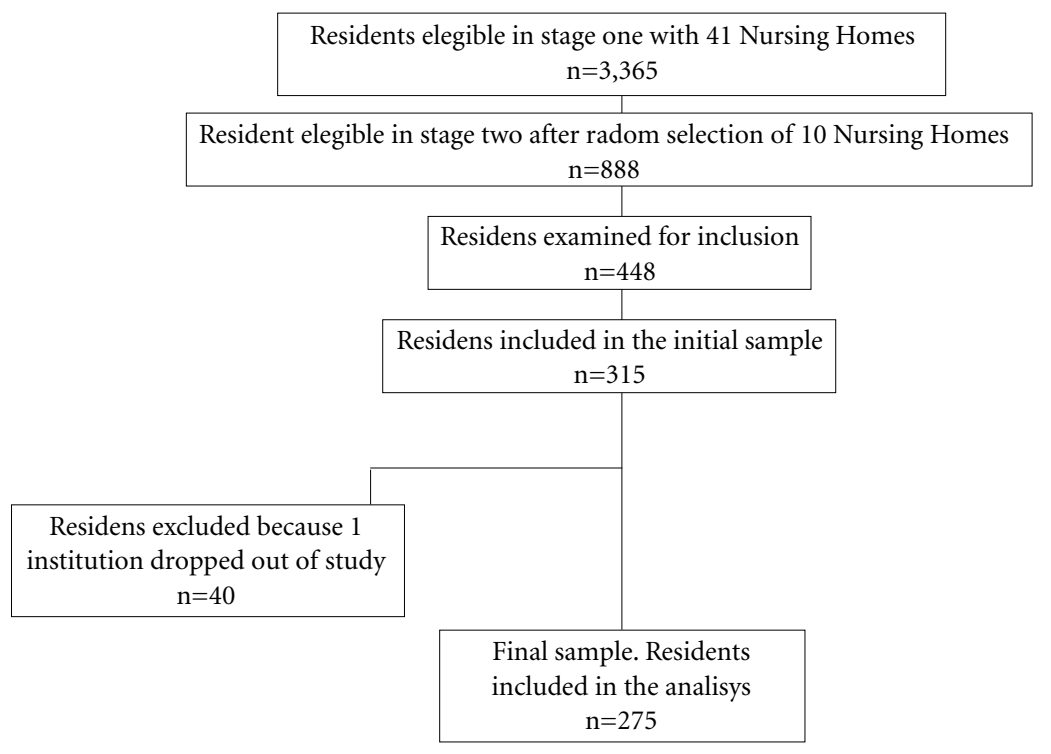

Figure 1. Numbers of individuals at each stage of the study. Murcia (Spain) 2015.

Table 1. Characteristics of the studied sample. Murcia (Spain) 2015.

\begin{tabular}{|c|c|c|c|}
\hline & $\begin{array}{c}\text { Patients with pDDI } \\
(\mathbf{n}=70)\end{array}$ & $\begin{array}{l}\text { Patients without pDDI } \\
(\mathbf{n}=205)\end{array}$ & Total $(n=275)$ \\
\hline & $\mathrm{n}(\%)$ & $\mathbf{n}(\%)$ & n (\%) \\
\hline Woman & $49(70,0)$ & $120(58,5)$ & $169(61,5)$ \\
\hline \multicolumn{4}{|l|}{ Age } \\
\hline 65-80 years & $26(37,1)$ & $89(43,4)$ & $115(41,8)$ \\
\hline$>80$ years & $44(62,9)$ & $115(56,1)$ & $159(57,8)$ \\
\hline Hypertension ${ }^{\star \star}$ & $48(68,6)$ & $105(51,2)$ & $153(55,6)$ \\
\hline Reumatics disease & $30(42,9)$ & $69(33,7)$ & $99(36,0)$ \\
\hline Diabetes & $19(27,1)$ & $44(21,5)$ & $63(22,9)$ \\
\hline $\mathrm{AF} /$ Heart failure ${ }^{*}$ & $28(40,0)$ & $28(13,7)$ & $56(20,4)$ \\
\hline Depression & $16(22,9)$ & $28(13,7)$ & $44(16,0)$ \\
\hline Stroke & $10(14,3)$ & $31(15,1)$ & $41(14,9)$ \\
\hline Respiratory disease & $23(32,9)$ & $13(6,3)$ & $36(13,1)$ \\
\hline Diuretics ${ }^{\star}$ & $42(60.0)$ & $47(22.9)$ & $89(50.9)$ \\
\hline Bronchodilators $^{\star}$ & $19(27.1)$ & $15(7.3)$ & $34(19.4)$ \\
\hline ACE inhibitor drug* & $38(54.3)$ & $83(40.5)$ & $121(69.1)$ \\
\hline $\mathrm{PPIs}^{\star}$ & $49(70.0)$ & $88(42.9)$ & $137(78.3)$ \\
\hline NSAIDs $^{\star}$ & $21(30.0)$ & $26(12.7)$ & 47 (26.9) \\
\hline Psycholeptics ${ }^{\star}$ & $41(58.6)$ & $117(57.1)$ & $158(90.3)$ \\
\hline Antithrombotics ${ }^{*}$ & $39(55.7)$ & $57(27.8)$ & $96(54.9)$ \\
\hline \multicolumn{4}{|l|}{ Number of drugs } \\
\hline $0-4^{*}$ & $2(2,9)$ & $79(38,5)$ & $81(29,5)$ \\
\hline $4-9$ & $31(44,3)$ & $106(51,7)$ & $137(49,8)$ \\
\hline $10-14^{*}$ & $28(40,0)$ & $20(9,8)$ & $48(17,5)$ \\
\hline \multirow[t]{2}{*}{$\geq 15$} & $9(12,9)$ & 0 & $9(3,3)$ \\
\hline & Mean \pm SD & Mean \pm SD & Mean \pm SD \\
\hline Age & $81,8 \pm 6,9$ & $81,5 \pm 8,0$ & $81,6 \pm 7,7$ \\
\hline Number of comorbidities & $3,8 \pm 1,7$ & $2,7 \pm 1,7$ & $3,0 \pm 1,8$ \\
\hline Number of drugs & $10 \pm 3,5$ & $5,4 \pm 3,1$ & $6,6 \pm 3,8$ \\
\hline
\end{tabular}


Table 2. Pairs of drugs frequently associated with relevant DDIs. Murcia (Spain) 2015.

\begin{tabular}{|c|c|c|c|}
\hline Interaction & $\%$ & Effects & Recommendation \\
\hline Diuretic-Bronchodilator & 15.6 & \multirow{8}{*}{$\begin{array}{l}\text { Hypokalemiant effects potentiation, } \\
\text { tachycardia and arrhythmias }\end{array}$} & \multirow[t]{8}{*}{ Avoid association } \\
\hline Furosemide - Salmeterol & 2.2 & & \\
\hline Salbutamol - Furosemide & 4.2 & & \\
\hline Furosemide- Formoterol & 3.4 & & \\
\hline Hidroclorotiazide - Salmeterol & 2.5 & & \\
\hline Salbutamol - Hidroclorotiazide & 1.7 & & \\
\hline Furosemide - Terbutaline & 0.8 & & \\
\hline Hidroclorotiazide - Terbutaline & 0.8 & & \\
\hline Diuretic - Digoxin & 10.1 & \multirow[t]{4}{*}{ Risk of digitalic intoxication } & \multirow{4}{*}{$\begin{array}{l}\text { Patient } \\
\text { monitoring }\end{array}$} \\
\hline Digoxin - Furosemide & 5.0 & & \\
\hline Digoxin - Espironolactone & 2.5 & & \\
\hline Digoxin - Hidroclorotiazide & 2.5 & & \\
\hline Anticoagulants - PPI & 7.6 & \multirow{2}{*}{$\begin{array}{l}\text { Possible potentiation of the } \\
\text { anticoagulant effect. Risk of bleeding }\end{array}$} & \multirow{2}{*}{$\begin{array}{l}\text { Patient } \\
\text { monitoring }\end{array}$} \\
\hline Acenocumarol - Omeprazol & 7.6 & & \\
\hline Calcium salts - Bisphosphonates & 6.7 & \multirow{3}{*}{$\begin{array}{l}\text { Possible reduction in the levels of } \\
\text { bisphosphonates, with the consequent } \\
\text { risk of reduction or loss of therapeutic } \\
\text { activity }\end{array}$} & \multirow{3}{*}{$\begin{array}{l}\text { Modification } \\
\text { dosing regimen }\end{array}$} \\
\hline Calcium carbonate - Alendronic & 5.0 & & \\
\hline Calcium carbonate - Risedronic & 1.7 & & \\
\hline Diuretics - NSAIDs & 5.7 & \multirow{6}{*}{$\begin{array}{l}\text { Possible loss of diuretic and } \\
\text { antihypertensive effects }\end{array}$} & \multirow{6}{*}{$\begin{array}{l}\text { Patient } \\
\text { monitoring }\end{array}$} \\
\hline Furosemide - Diclofenac & 2.5 & & \\
\hline Furosemide - Dexibuprofen & 0.8 & & \\
\hline Furosemide - Ibuprofen & 0.8 & & \\
\hline Furosemide - Piroxicam & 0.8 & & \\
\hline Torasemide - Ibuprofen & 0.8 & & \\
\hline Benzodiazepine - Levodopa & 4.9 & \multirow{6}{*}{$\begin{array}{l}\text { Possible loss of therapeutic activity of } \\
\text { levodopa }\end{array}$} & \multirow{6}{*}{$\begin{array}{l}\text { Patient } \\
\text { monitoring }\end{array}$} \\
\hline Bromazepam - levodopa & 1.7 & & \\
\hline Clonazepam - Levodopa & 0.8 & & \\
\hline Cloracepate - Levodopa & 0.8 & & \\
\hline Diazepam - Levodopa & 0.8 & & \\
\hline Lormetazepam - Levodopa & 0.8 & & \\
\hline Tiazhide - Calcium salts & 5.0 & \multirow{3}{*}{$\begin{array}{l}\text { Possible organic accumulation calcium, } \\
\text { which may lead toxic effects }\end{array}$} & \multirow{3}{*}{$\begin{array}{l}\text { Patient } \\
\text { monitoring }\end{array}$} \\
\hline $\begin{array}{l}\text { Calcium carbonate - } \\
\text { Hidroclorotiazide }\end{array}$ & 4.2 & & \\
\hline $\begin{array}{l}\text { Calcium carbonate - } \\
\text { Clortalidone }\end{array}$ & 0.8 & & \\
\hline Benzodiazepine - PPI & 3.4 & \multirow{2}{*}{$\begin{array}{l}\text { Possible increased plasma levels of } \\
\text { benzodiazepines }\end{array}$} & \multirow[t]{2}{*}{ Avoid monitoring } \\
\hline Diazepam - Omeprazol & 3.4 & & \\
\hline Beta blocker - Bronchodilator & 3.6 & \multirow[t]{5}{*}{ Can lead to severe bronchoconstriction } & \multirow{5}{*}{$\begin{array}{l}\text { Patient } \\
\text { monitoring }\end{array}$} \\
\hline Carvedilol - Formoterol & 0.9 & & \\
\hline Carvedilol - Salbutamol & 0.9 & & \\
\hline Carvedilol - Salmeterol & 0.9 & & \\
\hline Timolol - Salmeterol & 0.9 & & \\
\hline Beta adrenergics - Corticosteroids & 3.6 & \multirow{6}{*}{$\begin{array}{l}\text { Possible potentiation of beta agonist } \\
\text { hipokalemiant effect with risk of } \\
\text { tachycardia and other dysrhythmias }\end{array}$} & \multirow{6}{*}{$\begin{array}{l}\text { Patient } \\
\text { monitoring }\end{array}$} \\
\hline Formoterol - Deflazacort & 0.9 & & \\
\hline Formoterol - Prednisone & 0.9 & & \\
\hline Salbutamol - Deflazacort & 0.9 & & \\
\hline Salbutamol-Prednisone & 0.9 & & \\
\hline Others & 33.8 & & \\
\hline
\end{tabular}

PPI, proton pump inhibitors; NSAIDs, nonsteroidal anti-inflammatory. 
Table 3. Logistic regression analysis modelling the association of factors related to clinically relevant pDDIs. Murcia (Spain) 2015.

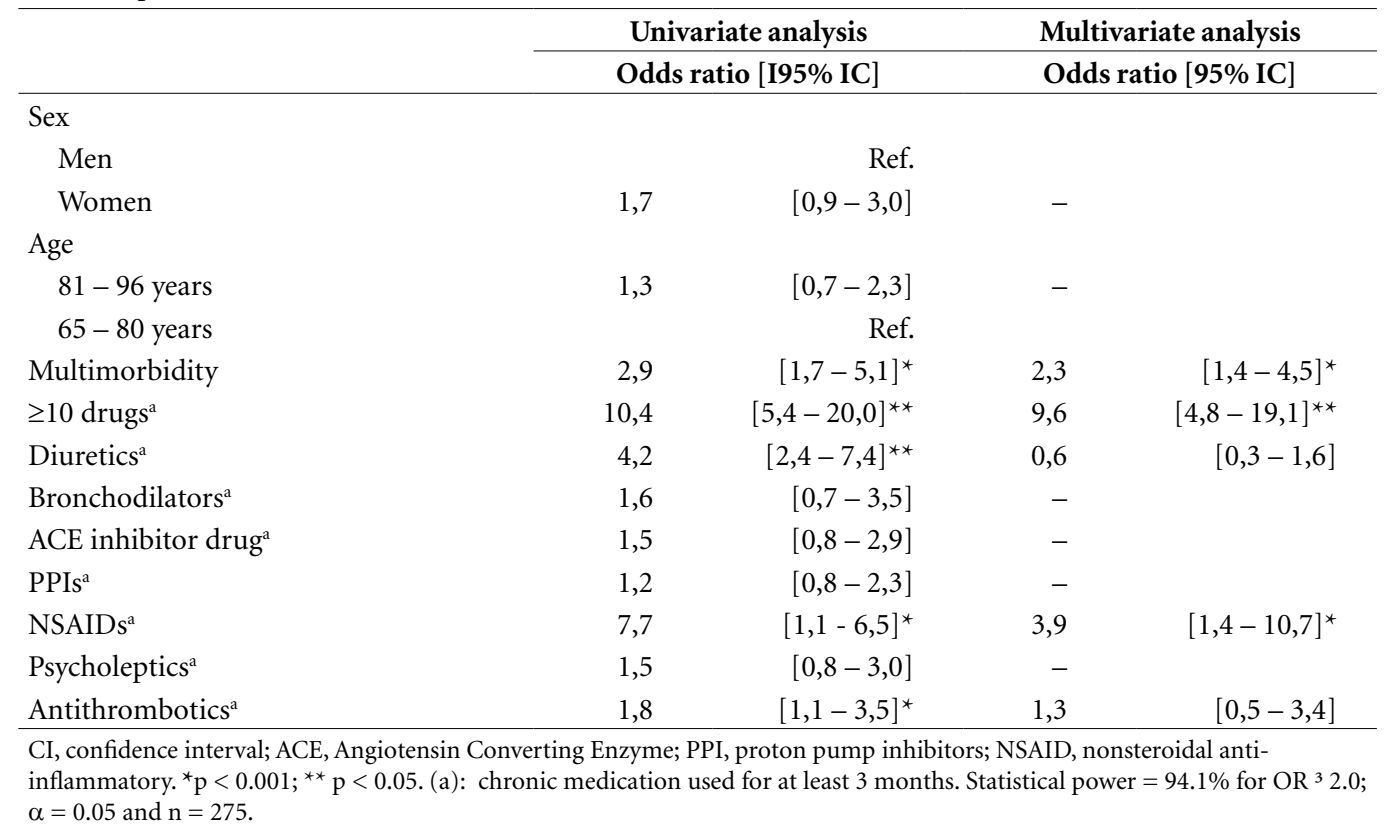

\section{Discussion}

This is the first study to address the prevalence of pDDIs in elderly residents in Spanish nursing homes. The prevalence of relevant pDDIs in institutionalized elderly people in the region of Murcia was high, and directly associated to polypharmacy, multimorbidity, as well as the use of anti-inflammatories and other pharmacological groups of high consumption ${ }^{15}$.

In relation to the relationship between polypharmacy and medicine use among patients, our results are consistent with other studies similar to our own ${ }^{9,16-18}$. Some of these studies have demonstrated that institutionalized people tend to use more drugs than those living freely within their community ${ }^{9}$. However, in Murcia, the average rate of drug intake within members of the community of the same age seems to be similar to the rate in our results ${ }^{18}$. The prevalence of multimorbidity, on other hand, is variant across most studies $^{18,19}$. This, perhaps, is due to the different criteria used to establish its definition; however, this is also true in the case of chronic diseases such as diabetes, rheumatic disorders and cardiovascular diseases.

In accordance to similar studies ${ }^{9,20}$, our study found that $25.5 \%$ of our subjects showed relevant pDDIs. However, only a few of these studies analyzed DDIs in institutionalized people. There exists a study carried out in Taiwan ${ }^{9}$, in which lower incidences of pDDIs were found. This result, however, is contingent on the fact that $70 \%$ of pDDIs were categorized as moderately relevant. Another recent study, carried out in Chi$\mathrm{na}^{20}$, reveals a higher prevalence $37.8 \%$ of the total); this result, however, should be interpreted in light of the different prescription criteria and the variant methods employed to evaluate the prevalence of pDDIs, something which has been extensively covered in scientific literature.

The evidence supports the existence of a causal link between multimorbidity and polypharmacy in the presence of pDDIs ${ }^{1,7-9,18}$. In our study, the presence of pDDIs is significantly associated with multiple disorders, a finding that correlates with the data in the literature ${ }^{1,8}$. In relation to the number of drugs, we found that patients who take ten or more drugs are more than nine times more likely to exhibit pDDIs. However, we found only a moderate relationship between the number of drugs and DDIs, while previous studies suggest that in some cases there is a lineal relationship ${ }^{21,22}$ and an exponential relationship in others $^{23,24}$, in relation to the number of drugs and the occurrence of pDDIs. Apart from other reasons, in our study, this could be explained by the fact that we have identified clinically relevant pDDIs; this is not the case in other studies.

A major limitation in our work arises when compared with the results of other studies, that is, the variability of available tools for the detection 
of pDDIs. In our case, we used BOT because it is a database that spans the Spanish pharmaceutical market, and also because it has a multi-checking system, which facilitates the detection of pDDIs in these patients, who are usually polymedicated. Another limitation could be considered in relation to the fact that we make reference to potential interactions, though we did not monitor the potentially adverse events they may trigger. However, based on the findings of other studies, it can be estimated that there is a high probability that such events occur ${ }^{6,25}$. Besides, since the information on drugs was garnered by existing database in each site and there was not guarantee of homogeneity between the various clinical information systems, the possibility of an information bias should be considered while interpreting the results. Prevalence of pDDIs could have been underestimated if any of the nursing homes tended to a low registration of pharmacological data. However, we tried to minimize this issue checking the data obtained with the reports of the medical staff. Lastly, data were obtained by means of a cross-sectional design, and therefore, do not give insight into the question of causality.

We believe that our findings are important because the results have been derived from a study conducted on a sample of patients who are over 65 and who are representative of the institutionalized demographic of this same age, thus crediting this study with external validity. In addition, the demographic and pathological characteristics of the patients included in our study are similar to those studied by other authors, ${ }^{9,20}$. Besides, the possibility of type II error is minimized in our study because the post-hoc power sample obtained is very large.

This study highlights the finding that eight drug groups are responsible for $70 \%$ of the interactions, which may allow for prioritizing ac- tions in patients receiving treatment with any of these drugs. In most cases it is difficult to replace the drug with a safer alternative (group effect). In these cases, it is recommended to monitor the patient to avoid the appearance of adverse effects. Analyzing the implications and adjusting to prescription frequency, it has been observed that the calcium salts, bronchodilators and diuretics may cause a significant interaction between approximately $40-50 \%$ of cases; it is a result that warrants due consideration because of the extensive use of these types of drugs to treat the elderly.

In most cases, after the detection of pDDIs the recommendation was made to monitor the patient $(80.7 \%)$. This is where we believe there is most opportunity for the pharmacist to develop their clinical practice by applying their knowledge and collaborating with the physician, clinicians can optimize drug treatments for the institutionalized elderly. A study reveals that the review of the treatments carried out by pharmacists integrated into multidisciplinary teams can reduce the number of prescription drugs and reduce the rate of mortality and morbidity associated with iatrogenic diseases derived from drug use ${ }^{26}$.

In conclusion, the findings of this study suggest that the prevalence of clinically relevant $\mathrm{pD}$ DIs is high in institutionalized elderly people, and could comprise a major health problem. These results reveal that a few pharmacological groups are responsible for most of the drug interactions. Strategies are needed in order to facilitate and make available the appropriate information to clinicians. There is also a need to promote the prevention of predictable and preventable adverse events that are caused by pDDIs, especially in high-risk demographics such as the institutionalized elderly and frail patients with several chronic diseases or polypharmacy.

\section{Collaborations}

JJ Gascón-Cánovas, ZAS Gama and C Iniesta-Navalón were involved in study conception and design ZAS Gama, EA Gutiérrez-Estrada and JF Sánchez-Ruiz were involved in study execution and acquisition of data. JF Sánchez-Ruiz and C Iniesta-Navalón, contributed to data analysis and interpretation. EA Gutiérrez-Estrada, O Harrington-Fernández and C Iniesta-Navalón drafted the manuscript. All authors provided substantial intellectual contributions and approved the final version of the manuscript. 


\section{References}

1. Galindo-Ocaña J, Gil-Navarro MV, García-Morillo JS, Bernabeu-Wittel M, Ollero-Baturone M, Ortiz-Camuñez MA. Drug-drug interactions in multicentre polypathological polymedicated patients. Rev Clin Esp 2010; 210(6):270-278.

2. Spain. Ministry of health and consumer affairs. APEAS Study Patient Safety in Primary Health Care. 2008. [cited 2013 Oct 18]. Available from: http://www.msc.es/ organizacion/sns/plancalidad/docs/estudio_apeas.pdf

3. Otero López MJ, Alonso Hernández P, Maderuelo Fernández JA, Ceruelo Bermejo J, Domínguez-Gil Hurlé A, Sánchez Rodríguez A. Prevalence and factors associated with preventable adverse drug events leading to hospital admission. Farm Hosp 2006; 30(3):161-170.

4. Martín MT, Codina C, Tuset M, Carné X, Nogué $\mathrm{S}$, Ribas J. Drug related problems as a cause of hospital admission. Med Clin (Barc) 2002; 118(6):205-210.

5. Malone DC, Abarca J, Hansten PD, Grizzle AJ, Armstrong EP, Van Bergen RC, Duncan-Edgar BS, Solomon SL, Lipton RB . Identification of serious drug-drug interactions: results of the partnership to prevent drugdrug interactions. Am J Geriatr Pharmacother 2004; 44(2):142-151.

6. Becker ML, Kallewaard M, Caspers PW, Visser LE, Leufkens HG, Stricker BH. Hospitalisations and emergency department visits due to drug-drug interactions: a literature review. Pharmacoepidemiol Drug Saf 2007; 16(6):641-651.

7. Lopez-Picazo JJ, Ruiz JC, Sanchez JF, Ariza A, Aguilera B, Lazaro D, Sanz GR. Prevalence and typology of potential drug interactions occurring in primary care patients. Eur J Gen Pract 2010; 16(2):92-99.

8. Secoli SR, Figueras A, Lebrao ML, Lima FD, Santos JL. Risk of potential drug-drug interactions among Brazilian elderly: a population-based, cross-sectional study. Drugs Aging 2010; 27(9):759-770.

9. Liao HL, Chen JT, Ma TC, Chang YS. Analysis of drugdrug interactions (DDIs) in nursing homes in Central Taiwan. Arch Gerontol Geriatr 2008; 47(1):99-107.

10. Mallet L, Spinewine A, Huang A. The challenge of managing drug interactions in elderly people. Lancet 2007; 370(9582):185-191.

11. Hanlon JT, Perera S, Newman AB, Thorpe JM, Donohue JM, Simonsick EM, Shorr RI, Bauer DC, Marcum ZA; Health ABC Study. Potential drug-drug and drug-disease interactions in well-functioning community-dwelling older adults. J Clin Pharm Ther 2017; 42(2):228-233

12. Nabovati E, Vakili-Arki H, Taherzadeh Z, Saberi MR, Medlock S, Abu-Hanna A, Eslami S. Information Technology-Based Interventions to Improve Drug-Drug Interaction Outcomes: A Systematic Review on Features and Effects. J Med Syst 2017; 41(1):12.

13. Consejo General del Colegio Oficial de Farmacéuticos (CGCOF). Base de datos del medicamento del Colegio Oficial de Farmacéuticos de España (BOT). Madrid: CGCOF; 2009.

14. Rodríguez-Terol A, Caraballo MO, Palma D, Santos-Ramos B, Molina T, Desongles T, Aguilar A. Quality of interaction database management systems. Farm Hosp 2009; 33(3):134-146.
15. Use of Nonsteroidal anti-inflammatory drugs in Spain, 1992-2006. [cited 2013 Oct 18]. Available from: http:// www.aemps.gob.es/medicamentosUsoHumano/observatorio/docs/AINE.pdf

16. Bjorkman IK, Fastbom J, Schmidt IK, Bernsten CB; Pharmaceutical Care of the Elderly in Europe Research (PEER) Groupl. Drug-drug interactions in the elderly. Ann Pharmacother 2002; 36(11):1675-1681.

17. Roughead EE, Kalisch LM, Barratt JD, Gilbert AL. Prevalence of potentially hazardous drug interactions amongst Australian veterans. Br J Clin Pharmacol 2010; 70(2):252-257.

18. Iniesta-Navalón C, Urbieta-Sanz E, Gascón-Cánovas JJ. Analysis of the drug interactions associated to domiciliary drug therapy in elderly hospitalized patients. Rev Clin Esp 2011; 211(7):344-351.

19. Elfau Mairal M, García Solsona J, Hernández Torres A. et al. Drug interaction study in patients with comorbidity. Aten Farm 2006; 8(2):79-86.

20. Lao CK, Ho SC, Chan KK, Tou CF, Tong HH, Chan A. Potentially inappropriate prescribing and drug-drug interactions among elderly Chinese nursing home residents in Macao. Int J Clin Pharm 2013; 35(5):805-812.

21. Astrand B, Astrand E, Antonov K, Petersson G. Detection of potential drug interactions - a model for a national pharmacy register. Eur J Clin Pharmacol 2006; 62(9):749-756.

22. Cruciol-Souza JM, Thomson JC. Prevalence of potential drug-drug interactions and its associated factors in a Brazilian teaching hospital. J Pharm Pharm Sci 2006; 9(3):427-433.

23. Cadieux RJ. Drug interactions in the elderly: how multiple drug drug use increases risk exponentially. Postgrad Med 1989; 86(8):179-186.

24. Sloan RW. Drug interactions. Am Fam Physician 1983; 27(2):229-238.

25. Tulner LR, Frankfort SV, Gijsen GJ, van Campen JP, Koks $\mathrm{CH}$, Beijnen JH. Drug-Drug Interactions in a Geriatric Outpatient Cohort. Drugs Aging 2008; 25(4):343-355.

26. Bootman JL, Harrison DL, Cox E. The health care cost of drug-related morbidity and mortality in nursing facilities. Arch Intern Med 1997; 157(18):2089-2096.

Artigo apresentado em 01/04/2017

Aprovado em 22/08/2017

Versão final apresentada em 24/08/2017 